\title{
PENGEMBANGAN GAME EDUKASI DIGITAL DAN IMPLEMENTASI PADA PEMBELAJARAN BIOLOGI MATERI PLANTAE SISWA SMA KELAS X
}

\author{
Muhammad Rizal Kurniawan' \\ Listika Yusi Risnani ${ }^{2}$ \\ ${ }^{1,2)}$ Program Studi Pendidikan Biologi FKIP, Univeristas Muhammadiyah Purwokerto \\ E-mail: ${ }^{1}$ muhammadrizalk23@gmail.com, ${ }^{2}$ listikayusirisnani@ump.ac.id
}

\begin{abstract}
Science and Technology in education demand teachers as educators with integrated innovations in technological developments. The media is used to improve understanding of educational game-based material with student characteristics. The research aims to develop and the feasibility of digital educational games on the Plantae SMA class X material. This type of research uses development $(R \& D)$. The research model used is ADDIE with five stages: (1) analyze, (2) design, (3) development, (4) implementation, and (5) evaluation. . The instrument used a questionnaire and test (Pretest-Postest). The questionnaire assessment data were analyzed using the quantitative descriptive test, the pre-test and post-test assessment data were analyzed using the N-Gain test. Based on the results of the game assessment analysis by media experts with a total score of 3.40 (very good), then the assessment by the material expert with a total score of 3.48 (very good), then the assessment by the teacher with a total score of 3.23 (very good), and assessment by students with a total score of 3.38 (very good). The implementation of the game "Adventure Of Plant" shows that there is an increase in the average pretest score of 57 and the average post-test score of 77, with the $\mathrm{N}$-Gain analysis result of 0.47 (moderate). Conclusion: digital education game research on Plantae material is suitable for use as a learning medium, but it has a (moderate) influence on student learning outcomes in understanding the concept of learning.
\end{abstract}

Kata kunci: ADDIE, Game Edukasi Digital, Materi Plantae, Media Pembelajaran.

\section{PENDAHULUAN}

Perkembangan Ilmu Pengetahuan dan Teknologi (IPTEK) pada abad-21 saat ini semakin pesat mendorong upaya-upaya pembaharuan dalam bidang pendidikan (Saputra dkk., 2017). Hal ini setara dengan standar proses pendidikan dasar dan menengah dalam kurikulum 2013, bahwa pemanfaatan teknologi informasi dan komunikasi dapat meningkatkan keefektifan dan efisiensi proses pembelajaran yang diharapkan dapat meningkatkan mutu pendidikan (Kemendikbud, 2016 ; Rusdi dkk., 2019)

Kegiatan proses pembelajaran yang efektif dan efisien tersebut mengharuskan guru mampu untuk menguasai Teknologi Informasi dan Komunikasi (TIK). Guru juga dituntut untuk dapat mengembangkan berbagai jenis teknologi informasi untuk kepentingan pembelajaran. Sehingga berbagai fasilitas sekolah yang berbasis TIK dapat dimanfaatkan oleh guru dengan maksimal (Sriwahyuni, 2016). Penggunaan TIK oleh guru untuk kepentingan pembelajaran dapat bermacam-macam baik dalam bentuk software maupun hardware. Software yang dapat dikembangkan oleh guru salah satunya dalam bentuk media pembelajaran (Priandana, 2015).

Media pembelajaran merupakan alat bantu yang di gunakan untuk menyampaikan informasi berupa materi pembelajaran (Falahudin, 2014). Penggunaan media pembelajaran dapat membantu siswa untuk mempermudah menyerap informasi berupa materi yang disampaikan. Selain itu penggunaan media pembelajaran juga mampu menumbuhkan 
minat dan ketertarikan siswa untuk belajar (Budiana dkk., 2015; Hikam, 2012)

Media pembelajaran memiliki ciri pokok utama yaitu suara, visual dan gerak (Muhson, 2010). Menurut (Munir, 2014), terdapat 4 macam media pembelajaran yaitu: 1) media audio, 2) media visual, 3) multimedia, dan 4) media benda asli dan orang. Masing-masing media pembelajaran memiliki kelebihan dan kekurangan dalam implementasi sebagai media pembelajaran. Salah satu media yang efektif digunakan sebagai media pembelajaran adalah multimedia.

Multimedia merupakan media yang berbasis audio visual yang di dalamnya terdapat berbagai unsur seperti teks, animasi, gambar, suara dan bahkan video (Panjaitan dkk., 2020). Kelebihan penggunaan multimedia dalam proses pembelajaran salah satunya untuk membangkitkan minat dan motivasi belajar siswa (Supriyono, 2019).

Pembelajaran dengan menggunakan multimedia oleh guru selama ini masih terbatas pada penggunaan powerpoint, video dan foto. Hal ini menyebabkan aktivitas belajar siswa sebatas melihat dan mendengar. belum sampai pada siswa melakukan aktivitas belajar sesuatu / learning by doing. Salah satu multimedia yang memungkinkan siswa untuk aktif dalam pembelajaran yaitu game edukasi (Herniati dkk., 2017; Panjaitan dkk., 2020)

Game edukasi adalah permainan yang digunakan untuk merangsang daya pikir siswa dalam meningkatkan konsentrasi, memperoleh informasi serta mampu mempermudah siswa dalam meningkatkan pemahaman materi (Hikam, 2012). Adanya konten pembelajaran di dalam game, sehingga game edukasi dapat di gunakan sebagai sebuah sistem instruksional. Game edukasi dapat digunakan untuk meningkatkan minat dan motivasi belajar serta memberikan pengalaman baru yang menarik bagi siswa dalam kegiatan pembelajaran (Arif, 2016)

Salah satu game edukasi yang relevan dikembangkan di era digital saat ini adalah game edukasi digital. Game edukasi digital merupakan game edukasi yang pengoperasianya menggunakan perangkat digital seperti komputer, laptop dan Handphone (Ramansyah, 2015). Penelitian terdahulu menyatakan bahwa pengembangan game (game development) saat ini mengarah ke dalam industri game edukasi digital (Sriwahyuni, 2016)

Pengembangan game edukasi digital penting untuk di kembangkan, mengingat pengguna game semakin meningkat dikalangan remaja. Remaja saat ini memiliki kondisi ketergantungan terhadap teknologi digital yang di sebut dengan digital native (Firdos, 2012). Digital native merupakan pemanfaatan teknologi dalam rangka memenuhi kebutuhan kegiatan sehari-hari (Dopo dkk., 2016; Risnani dkk., 2019). Kondisi digital native yang terjadi saat ini menjadi peluang dalam mengembangkan game edukasi digital sebagai sarana belajar siswa.

Game edukasi digital dirancang untuk membimbing siswa secara aktif menggali informasi, memperkaya pengetahuan dan strategi saat bermain (Novaliendry, 2013). Secara tidak langsung siswa akan melakukan proses belajar secara mandiri. Selain itu, game edukasi digital juga mempunyai kelebihan dari segi tampilan seperti teks, audio, video, grafik, animasi, dan interaktivitas sehingga diharapkan dapat menarik minat siswa untuk belajar. Hal tersebut menjadikan penggunaan game edukasi digital dapat meningkatkan minat belajar siswa secara signifikan (Yudasmara dkk., 2015).

Hasil penelitian oleh (Pramita, 2016), menunjukkan adanya data hasil penelitian sebesar $70 \%$ siswa tertarik dengan game edukasi digital sebagai media pembelajaran. Pembelajaran yang menyenangkan akan memberikan rangsangan terhadap proses belajar sehingga informasi dapat diterima dengan baik. Selain dapat meningkatkan minat, bermain juga dapat membantu siswa untuk 
memahami materi dengan mudah (Rahman dkk., 2016; Setyawan, W. C. dkk., 2019).

Pada mata pelajaran biologi, materi plantae memiliki cakupan materi yang cukup luas. Berdasarkan kompetensi dasar mencangkup tentang pengklasifikasian tumbuhan, berdasarkan ciri-ciri umum seperti ciri tubuh, cara hidup, habitat, dan cara reproduksinya (Rahma, 2014). Berdasarkan kompetensi dasar tersebut, siswa dituntut untuk menguasai dasar klasifikasi pada materi plantae. Proses menyampaikan informasi dilakukan agar siswa dapat memahami konsep-konsep dasar materi plantae (Nining dkk., 2019).

Pemahaman konsep merupakan kemampuan siswa dalam menguasai meateri secara ilmiah maupun penerapanya dalam kehidupan sehai-hari. Pemahaman terhadap konsep akan lebih memudahkan siswa dalam memahami materi pembelajaran. Pembelajaran melalui game edukasi digital diharapkan mampu membantu siswa dalam memahami konsep materi plantae dengan baik (Noviyanti, 2014).

Penelitian penggunaan game edukasi digital dalam meningkatkan pemahaman konsep sudah banyak dilakukan, seperti yang pernah dilakukan. Penelitian oleh (Rohwati, 2012), menyatakan bahwa pengembangan game edukasi sebagai media pembelajaran materi sistem pernapasan di kelas XI SMA. Penggunaan game edukasi digital untuk meningkatkan pemahaman konsep pada materi plantae belum pernah dilaporkan. Sehingga perlu adanya pengembangan game edukasi digital untuk materi plantae.

Penelitian tentang pengembangan game edukasi digital sudah banyak dilaporkan. Pada jenjang SD pernah dilaporkan oleh (Wulandari dkk., 2017), bahwa pengembangan multimedia berbasis game pada mata pelajaran IPA untuk sekolah dasar. Pada jenjang SMP pernah di laporkan oleh Lufri (2017), tentang pengembangan game edukasi visual novel berbasis pembangunan karakter pada materi pelestarian lingkungan pada kelas
VII. Pada jenjang SMA dilaporkan oleh (Sari dkk., 2014), bahwa pengembangan game edukasi kimia berbasis Role Playing Game (RPG) pada materi struktur atom sebagai media pembelajaran mandiri untuk siswa kelas X SMA.

Sebelum di implementasikan secara luas, produk pengembangan perlu dilakukan uji kelayakan. Media pembelajaran dapat dikatakan layak jika terdapat 3 komponen penilaian didalamnya, yaitu 1) kelayakan isi, 2) kelayakan Bahasa, dan 3) kelayakan penyajian. Dalam proses menentukan uji kelayakan game edukasi digital terdapat angket penilaian game edukasi digital yang diperoleh dari hasil uji oleh ahli media, ahli materi, guru mata pelajaran dan siswa (Anbia, 2013).

Penelitian ini bertujuan untuk mengetahui tingkat kelayakan game edukasi digital pada materi plantae. Rumusan masalah pada penelitian ini yaitu mengembangkan game edukasi digital untuk meningkatkan pemahaman konsep pada materi plantae.

\section{METODE}

Penelitian dilaksanakan pada bulan Januari hingga Agustus 2020. Perancangan dan pembuatan dilakukan di Laboratorium Multimedia Pembelajaran Universitas Muhamadiyah Purwokerto. Implementasi dilakukan di SMAN 1 Kutasari Kabupaten Purbalingga. Hasil dari penelitian ini adalah game edukasi digital yang mencangkup materi pembelajaran Biologi khususnya materi Plantae.

Jenis penelitian pengembangan dilakukan menggunakan model ADDIE. Model ADDIE adalah model pengembangan desain pembelajaran yang sistematik, hal ini dapat diketahui dari langkah-langkah pengembangan yang ada didalamnya. Terdapat lima tahapan atau langkah pengembangan dalam model ADIIE yaitu sebagai berikut: 1) Analysis, 2) Design, 3) Development, 4) Implementation, dan 5) Evaluation. (Dwiyono, 2017) 
Berdasarkan sumber, berikut lima tahapan yang harus dilakukan pada penelitian model pengembangan ADDIE :

\section{Analysis (Analisis)}

Tujuan dilakukannya analisis yaitu untuk mengetahui kebutuhan game edukasi digital di sekolah. Analisis dilakukan melalui observasi pembelajaran biologi dan wawancara terhadap guru dan siswa. Kebutuhan game yang berkaitan dengan tahapan analisis yaitu: Analisis karakteristik siswa, Kompetensi Dasar (KD) dan indikator, tujuan instruksional, analisis media pembelajaran.

\section{Design (Perancangan)}

Pada tahap design dilakukan perancangan yang berkaitan dengan kebutuhan game edukasi digital. Perancangan yang dilakukan yaitu 1) desain materi, 2) desain flowchart, 3) desain user interface, 4) desain asset game (button, background, sound dll).

\section{Development (Pengembangan)}

Pada tahap pengembangan, peneliti membuat asset game berdasarkan hasil desain. Pembuatan asset game menggunakan aplikasi Adobe Ilustrator CS6, sedangkan untuk pengembangan game edukasi digital menggunakan aplikasi "Unity 2D version 2019.4.1fl". Setelah proses pengembangan asset dan penyusunan game selesai maka selanjutnya game akan divalidasi oleh ahli media dan ahli materi sebelum di implementasikan.

\section{Implementation (Penerapan)}

Pada tahap implementasi, game di uji cobakan kepada siswa. Siswa memberikan penilaian game edukasi digital berupa angket penilaian game. Hasil penilaian belajar siswa dilakukan dalam bentuk pre-test dan post-test. Penilaian game edukasi digital juga dilakukan oleh guru melalui angket penilaian game. Implementasi dilakukan pada siswa kelas $\mathrm{X}$ MIPA SMA N 1 Kutasari. Jumlah siswa dengan total 60 yang terdiri dari 31 siswa kelas X MIPA 1 dan 29 siswa kelas X MIPA 2.
Instrumen berupa angket penilaian yang terdiri dari 35 butir pernyataan untuk ahli media, 25 butir pernyataan untuk ahli materi, 30 butir pernyataan untuk guru, serta 35 butir pernyataan untuk siswa. Jenis angket yang digunakan adalah angket dengan menggunakan skala linkert. Skala linkert terdiri dari 4 skala yang telah di modifikasi menjadi TS (Tidak Setuju) dengan bobot skor 1, KS (Kurang Setuju) dengan bobot skor 2, S (Setuju) dengan bobot skor 3 dan SS (Sangat Setuju) merupakan skor maksimal dengan skor 4 . Instrumen lain yang digunakan dalam pengumpulan data yaitu soal pre-test dan post-test. Soal tersebut terdiri dari 20 butir soal pilihan ganda dan 5 butir soal uraian.

Penelitian ini menggunakan 2 metode dalam melakukan analisis data. Metode analisis data yang di gunakan adalah analisis data deskriptif kuantitatif dan deskriptif kualitatif. Analisis data deskriptif kuantitatif digunakan untuk mengetahui kelayakan game edukasi berdasarkan data yang diperoleh dari hasil angket ahli media, ahli materi, guru dan siswa. Sedangkan analisis deskriptif kualitatif bertujuan untuk mengetahui penilaian game edukasi digital yang di analisis dari hasil komentar dan saran yang di berikan oleh ahli media, ahli materi, guru dan juga dari siswa. Adapun langkahlangkah yang harus dilakukan dalam tahapan analisis data adalah sebagai berikut:

1. Mengubah hasil isian angket yang bersifat kualitatif menjadi kuantitatif dengan skala likert (empat skala).

2. Menentukan rata-rata skor pada setiap item pernyataan berdasarkan pedoman kriteria penilaian sebagai berikut:

Tabel 1. Pedoman Kriteria Penilaian Game Edukasi

\begin{tabular}{|l|c|}
\hline \multicolumn{1}{|c|}{ Interval Nilai } & Kriteria \\
\hline $\mathrm{Mi}+1,5 \mathrm{Sbi}<\mathrm{X}$ & Baik Sekali \\
\hline $\mathrm{Mi}+1,5 \mathrm{Sbi}<\mathrm{X} \leq \mathrm{Mi}+$ & Baik \\
$1,5 \mathrm{Sbi}$ & \\
\hline $\mathrm{Mi}-1,5 \mathrm{Sbi}<\mathrm{X} \leq \mathrm{Mi}+1,5$ & Cukup Baik \\
$\mathrm{Sbi}$ & \\
\hline $\mathrm{Mi}-1,5 \mathrm{Sbi}<\mathrm{X} \leq \mathrm{Mi}+1,5$ & Kurang Baik \\
$\mathrm{Sbi}$ & \\
\hline
\end{tabular}


\begin{tabular}{|l|l|}
\hline $\mathrm{X} \leq \mathrm{Mi}-1,5$ Sbi & Tidak Baik \\
\hline
\end{tabular}

Sumber : (Risnani \& Adita., 2019)

Keterangan :

$\mathrm{X}$ : rerata skor aktual

Mi : mean ideal

Sbi : simpangan baku ideal

Mi : $1 \frac{1}{2} \times$ (skor tertinggi ideal + skor terendah ideal)

Sbi : $1 / 6 \times$ (skor tertinggi ideal - score terendah ideal)

Selanjutnya diperlukan uji analisis data untuk mengetahui pengaruh game edukasi digital sebagai media pembelajaran Biologi materi Plantae yang diperoleh dari hasil belajar siswa. Maka dari itu data yang di peroleh dari hasil belajar siswa dianalisis menggunakan uji $N$-Gain dengan rumus sebagai berikut :

$N-$ Gain $=\frac{\text { score PostTest }- \text { Score PreTest }}{\text { Score Maksimal Ideal }- \text { Score PreTest }}$

Berdasarkan rumus tersebut, maka dapat diperoleh kategori penilaian yang di gunakan sebagai pedoman nilai indeks $N$ Gain :

Tabel 2. Kategori Pedoman Penilaian N-

\begin{tabular}{|l|c|}
\multicolumn{1}{c}{ Gain } \\
\hline Nilai Indeks Gain & Kategori \\
\hline $\mathrm{N}-$-Gain $>0,70$ & Tinggi \\
\hline $0,30<\mathrm{N}-$ Gain $\leq 0,70$ & Sedang \\
\hline N-Gain $\leq 0,30$ & Rendah \\
\hline \multicolumn{2}{|c|}{ Sumber : (Dewi dkk., 2017) }
\end{tabular}

\section{Evaluation (Evaluasi)}

Evaluasi merupakan tahap untuk mengetahui tingkat kelayakan, serta kualitas game edukasi digital sebagai media pembelajaran biologi. Evaluasi dapat dilakukan dengan melihat hasil penilaian oleh siswa dan guru dari instrumen game.

\section{HASIL}

Advanture Of Plant merupakan game edukasi digital yang dirancang sebagai media pembelajaran Biologi. Game Advanture of Plant's menjadi media pembelajaran untuk siswa kelas X SMA. Pengembangan game "Adventure of Plant" dilakukan menggunakan model pengembangan ADDIE adalah sebagai berikut :

1. Analyze

a. Analisis Siswa
Siswa di SMA N 1 Kutasari sudah terbiasa menggunakan peralatan beberbasis teknologi informasi seperti smartphone dan laptop sebagai sarana untuk belajar. Hal ini juga di dukung oleh ketersediaan $\mathrm{Wi}$-Fi dan computer sebagai sarana pendukung belajar siswa. Hasil wawancara menunjukan bahwa siswa terbiasa bermain game digital, namun game digital yang dimainkan oleh kebanyakan siswa adalah game non edukasi. Hasil angket kebutuhan media game edukasi digital menunjukan bahwa siswa dengan menggunakan media pembelajaran berbasis game edukasi digital memiliki pengaruh yang signifikan sebesar 90\%. Hal ini menunjukkan bahwa rata-rata siswa dalam penggunaan smartphone setiap harinya sekitar 6-9 jam.

b. Analisis KD dan Indikator

Kompetensi Dasar (KD) dan indikator yang dikembangkan untuk pembuatan game edukasi digital "Advanture of Plant" yaitu berdasarkan KD 3.8 silabus mata pelajaran Biologi Kelas $X$ MIPA materi Plantae. Indikator pembelajaran yang dikembangkan untuk mencapai tujuan pembelajaran sesuai dengan Kompetensi Dasar (KD) yaitu sebagai berikut :

Tabel 3. Indikator Pembelajaran

\begin{tabular}{|c|l|}
\hline No & \multicolumn{1}{|c|}{ Indikator } \\
\hline 1 & $\begin{array}{l}\text { Membandingkan ciri umum dovisio } \\
\text { dalam kingdom Plantae (tumbuhan). }\end{array}$ \\
\hline 2 & $\begin{array}{l}\text { Mengetahui ciri-ciri tubuh, cara } \\
\text { hidup, habitat dan reproduksi } \\
\text { tumbuhan lumut. }\end{array}$ \\
\hline 3 & $\begin{array}{l}\text { Mengetahui ciri-ciri tubuh, cara } \\
\text { hidup, habitat dan reproduksi } \\
\text { tumbuhan paku. }\end{array}$ \\
\hline 4 & $\begin{array}{l}\text { Mengetahui ciri-ciri tubuh, cara } \\
\text { hidup, habitat dan reproduksi } \\
\text { tumbuhan berbiji. }\end{array}$ \\
\hline 5 & $\begin{array}{l}\text { Mengetahui manfaat dan peranan } \\
\text { tumbuhan dalam ekosistem, ekonomi } \\
\text { dan dampak turunya keanekaragaman } \\
\text { tumbuhan bagi ekosistem. }\end{array}$ \\
\hline
\end{tabular}

c. Analisis Tujuan Instruksional 
Pada tahap ini dikembangkan tujuan pembelajaran sesuai indikator pembelajaran KD 3.8 materi Plantae kelas X MIPA sebagai berikut:

Tabel 4. Tujuan Instruksional

\begin{tabular}{|c|l|}
\hline No & Tujuan Instruksional \\
\hline 1 & $\begin{array}{l}\text { Siswa dapat membandingkan ciri umum } \\
\text { dovisio dalam kingdom Plantae } \\
\text { (tumbuhan) melalui game edukasi digital } \\
\text { dengan baik dan benar. }\end{array}$ \\
\hline \multirow{2}{*}{3} & $\begin{array}{l}\text { Siswa dapat mengetahui ciri-ciri tubuh, } \\
\text { cara hidup, habitat dan reproduksi } \\
\text { tumbuhan lumut melalui game edukasi } \\
\text { digital dengan baik dan benar. }\end{array}$ \\
\hline 3 & $\begin{array}{l}\text { Siswa dapat mengetahui ciri-ciri tubuh, } \\
\text { cara hidup, habitat dan reproduksi } \\
\text { tumbuhan paku melalui game edukasi } \\
\text { digital dengan baik dan benar. }\end{array}$ \\
\hline 4 & $\begin{array}{l}\text { Siswa dapat mengetahui ciri-ciri tubuh, } \\
\text { cara hidup, habitat dan reproduksi } \\
\text { tumbuhan berbiji melalui game edukasi } \\
\text { digital dengan baik dan benar. }\end{array}$ \\
\hline \multirow{2}{*}{5} & $\begin{array}{l}\text { Siswa dapat mengetahui manfaat dan } \\
\text { peranan tumbuhan dalam ekosistem, } \\
\text { ekonomi dan dampak turunya } \\
\text { keanekaragaman tumbuhan } \\
\text { ekosistem melalui game edukasi digital } \\
\text { dengan baik dan benar. }\end{array}$ \\
\hline
\end{tabular}

d. Analisis Media Pembelajaran

Hasil observasi terhadap pembelajaran di kelas menunjukan bahwa kegiatan pembelajaran Biologi materi plantae kelas X SMA N 1 Kutasari untuk media pembelajaran masih sebatas pada penggunaan Power Point (PPT), video, gambar. Selain itu hasil wawancara terhadap guru biologi menunjukan bahwa untuk pembelajaran Biologi khususnya materi Plantae kelas X MIPA SMA N 1 Kutasari belum pernah menggunakan game edukasi digital sebagai media pembelajaran. Keterbatasan guru dalam membuat dan melakukan pengembangan game edukasi digital manjadi pengaruh terhadap penggunaan game edukasi digital sebagai media pembelajaran. Sehingga dapat dikatakan penggunaan game edukasi digital menjadi suatu hal baru yang digunakan sebagai media pembelajaran.

2. Design

a. Desain materi

Membuat peta konsep materi bedasarkan indikator dan tujuan instruksional pada materi kingdom plantae. Ruang lingkup materi plantae terdiri atas 3 sub pokok bahasan utama yaitu : pengertian umum kingdom plantae, ciriciri umum (klasifikasi tumbuhan lumut, paku dan berbiji) dan manfaat serta peranan keanekaragaman ekosistem tumbuhan bagi ekosistem dan ekonomi.

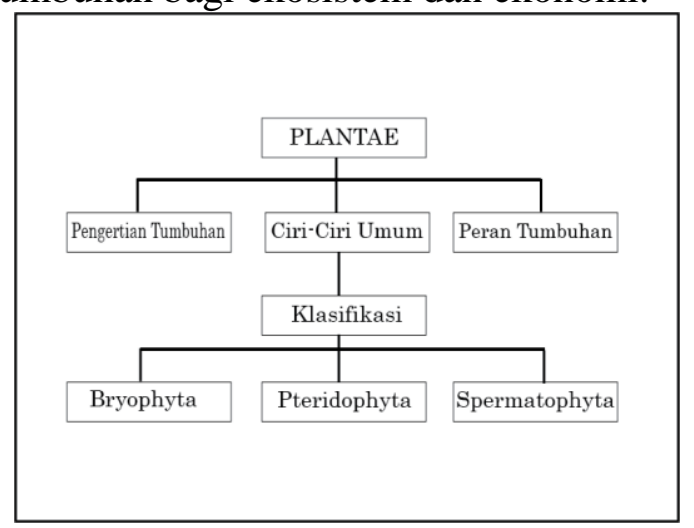

Gambar 1. Desain Materi

\section{b. Mendesain flowchart game}

Merupakan proses perancangan desain game edukasi dari awal main sampai dengan akhir game dalam bentuk desain sketsa yang di susun membentuk alur permainan di dalam game menjadi story board. Story board merupakan rancangan yang memperlihatkan fungsifungsi yang digunakan secara berurutan dalam suatu sistem. Story board game "Advanture of Plant" dapat dilihat pada gambar berikut ini:

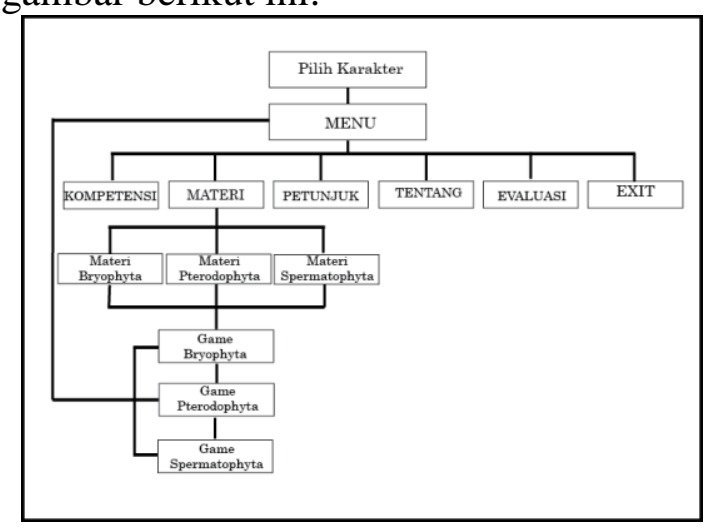

Gambar 2. Desain Flowchart

\section{c. Mendesain asset game}

Asset game di susun sesuai dengan karakter pengguna game yaitu siswa kelas X MIPA SMA N 1 Kutasari. Aset game di desain meliputi background, button, 
karakter, visualisasi materi dan sound. Hasil desain asset game adalah sebagai berikut:
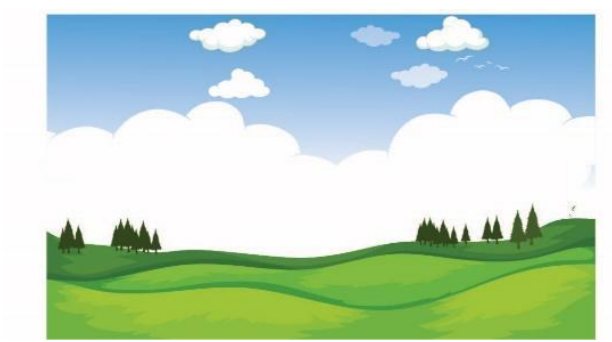

Gambar 3. Asset Background

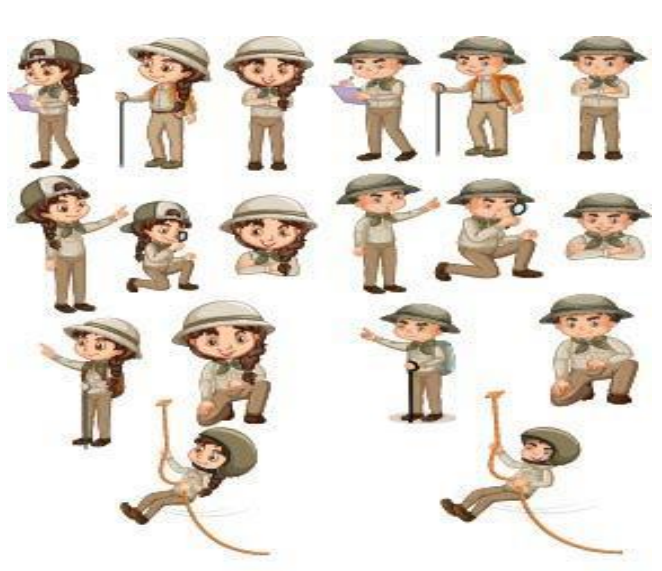

Gambar 4. Asset User

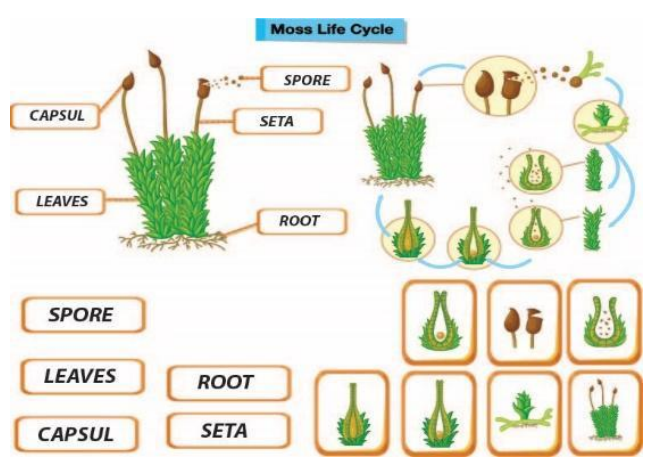

Gambar 5. Asset Tumbuhan

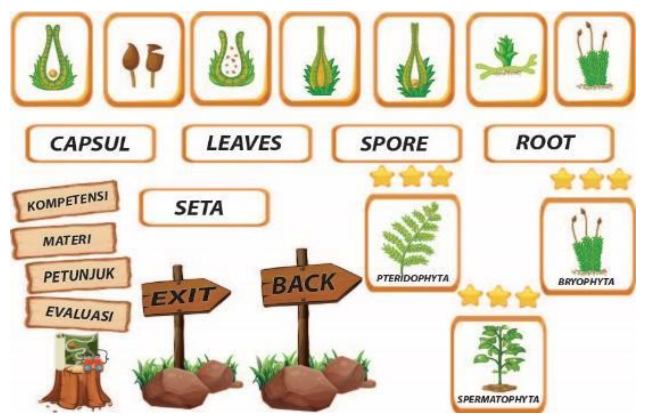

Gambar 6. Asset Button
Perancangan user interface bertujuan untuk memudahkan siswa dalam memahami dan mengoperasikan sistem dalam game. Selain memudahkan dalam mengoprasikan game, desain tampilan dan navigasi dalam game sangat diperhatikan. Sehingga akan memudahkan mobilitas pengguna saat memainkan game. Hasil perancangan user interface adalah sebagai berikut:

\begin{tabular}{|c|}
\hline KOMPETENSI \\
\hline MAIN \\
\hline PETUNJUK \\
\hline TENTANG \\
\hline EVALUASI \\
\hline
\end{tabular}

Gambar 7. Desain User Interface

\section{Development}

Berikut ini merupakan tampilan game "Advanture of Plant" yang sudah dikembangkan berdasarkan desain asset yang dibuat:

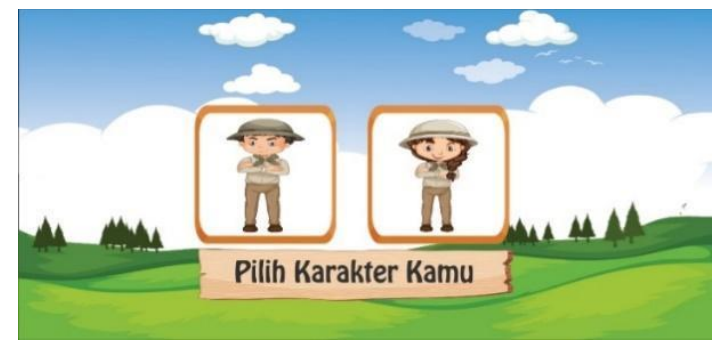

Gambar 8. Tampilan Awal

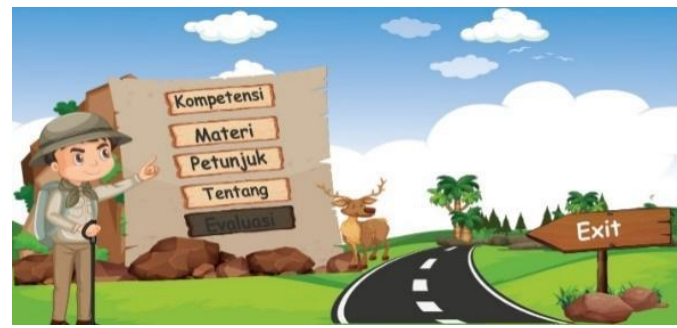

Gambar 9. Tampilan Menu

d. Perancangan user interface 


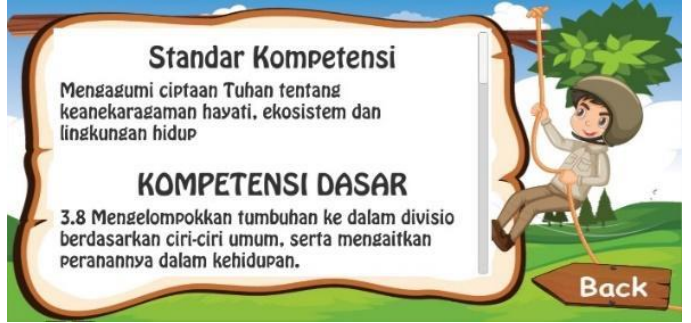

Gambar 10. Tampilan Kompetensi

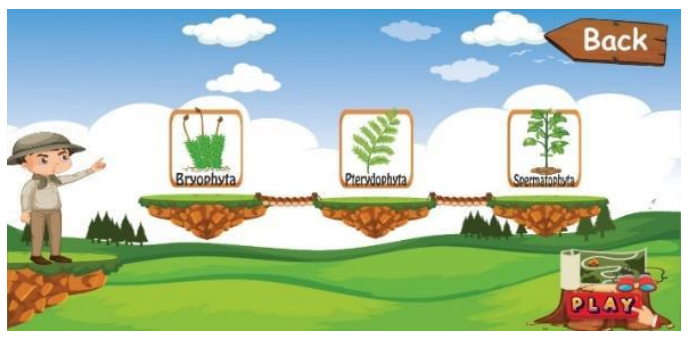

Gambar 11. Tampilan Awal Materi

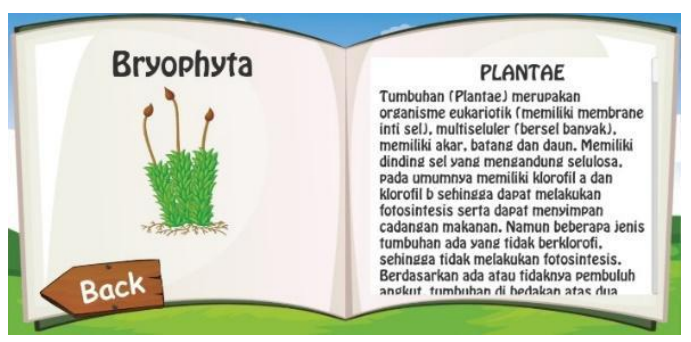

Gambar 12. Halaman Materi Tumbuhan Bryophyta

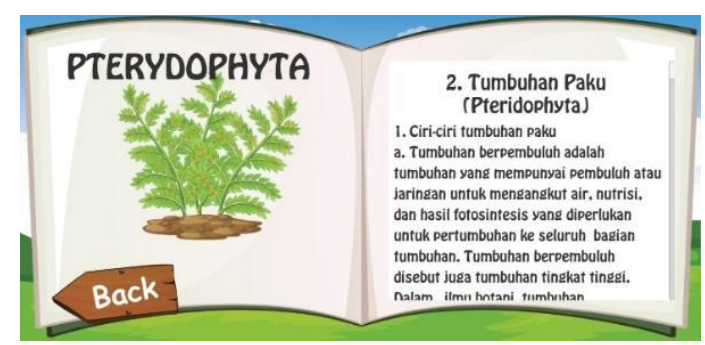

Gambar 13. Halaman Materi Tumbuhan Pteridophyta

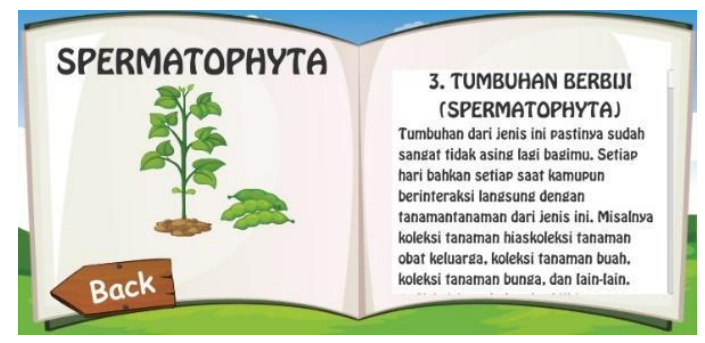

Gambar 14. Halaman Materi Tumbuhan Spermatophyta

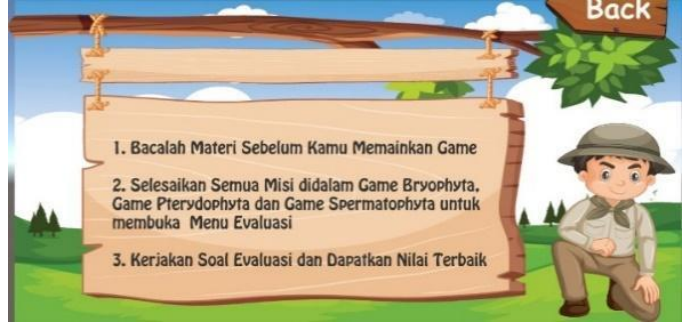

Gambar 15. Halaman Petunjuk Game

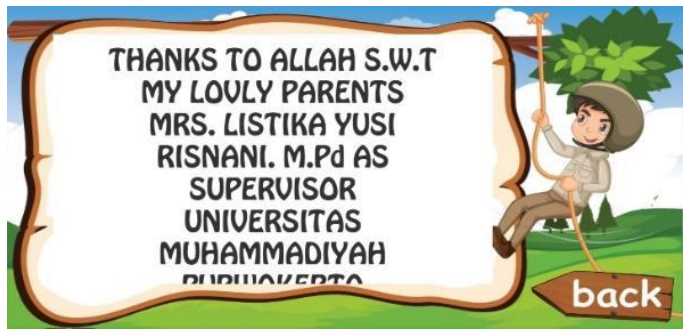

Gambar 16. Halaman Tentang

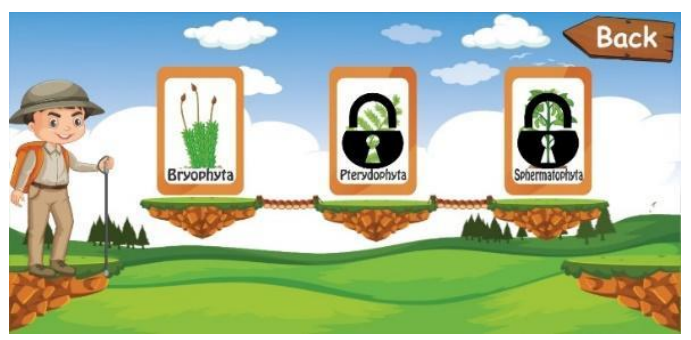

Gambar 17. Halaman Level Game

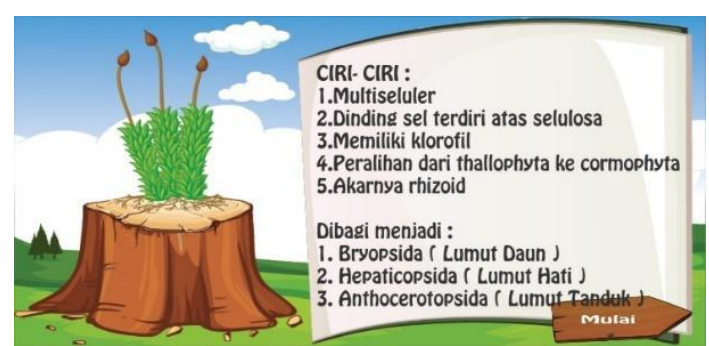

Gambar 18. Halaman Sebelum Mulai Game

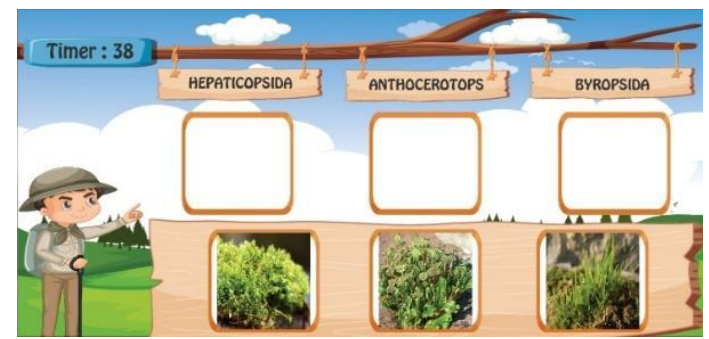

Gambar 19. Halaman Game Bryophyta 1 


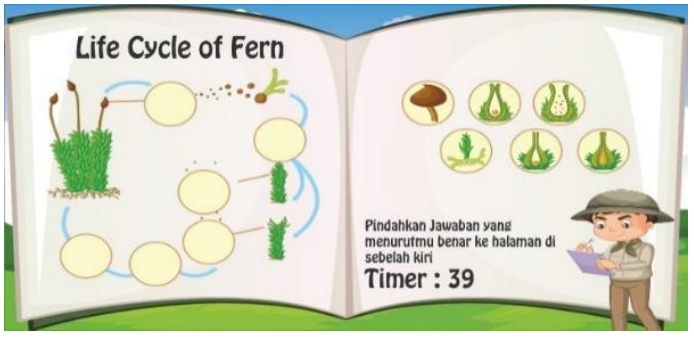

Gambar 20. Halaman Game Bryophyta 2

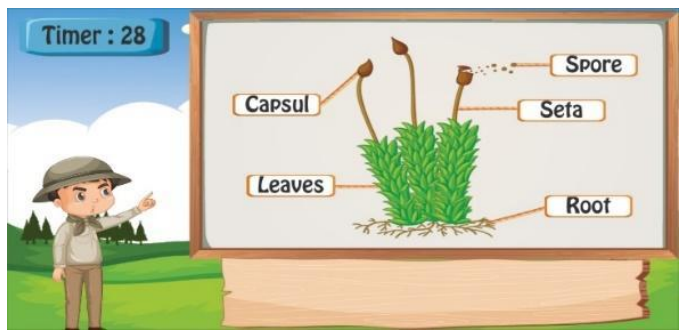

Gambar 21. Halaman Game Bryophyta 3

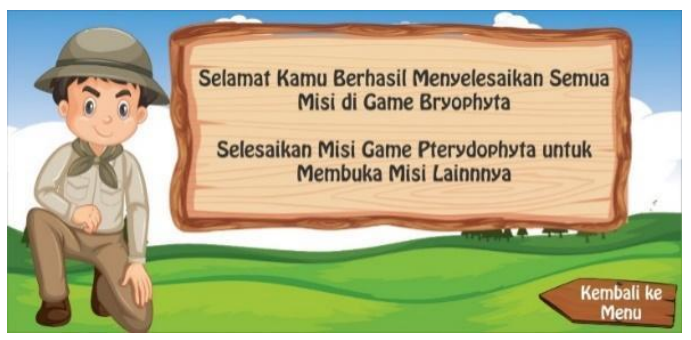

Gambar 22. Halaman Umpan Balik

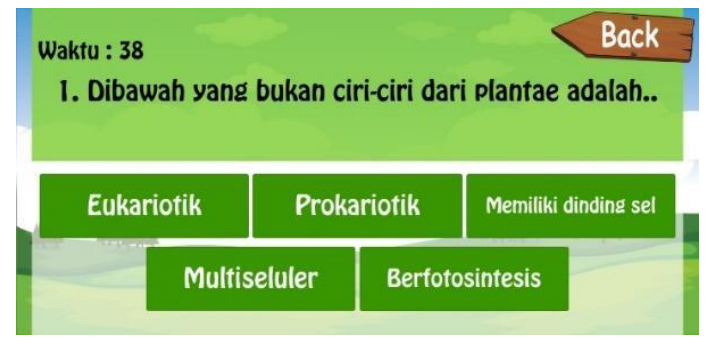

Gambar 23. Halaman Soal Evaluasi

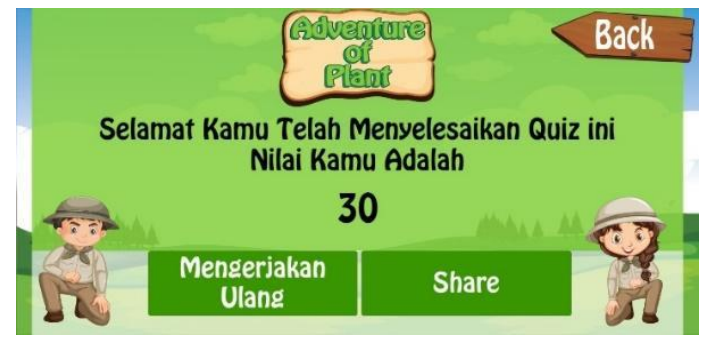

Gambar 24. Halaman Jumlah Score Evaluasi

Game edukasi digital yang telah dikembangkan di validasi oleh ahli media dan ahli materi dengan hasil yang dapat dilihat pada gambar berikut ini:

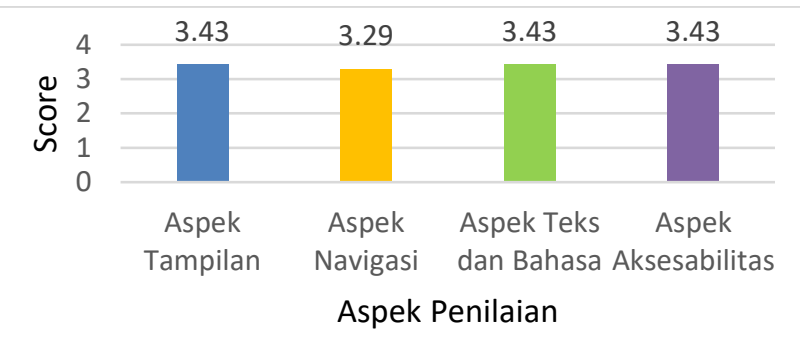

Gambar 25. Grafik Tanggapan Ahli Media

Hasil validasi oleh ahli media menunjukan bahwa dari aspek media, game memperoleh hasil score rata-rata 3,40 (baik sekali). Adapun rincian pada setiap aspek yaitu aspek tampilan memperoleh rata-rata score 3,43 (baik sekali). Untuk aspek navigasi memperoleh rata-rata score 3,29 (baik), aspek teks dan Bahasa memperoleh rata-rata score 3,43 (baik sekali) dan untuk aspek aksesabilitas mendapatkan hasil dengan jumlah rata-rata score 3,43 (baik sekali).

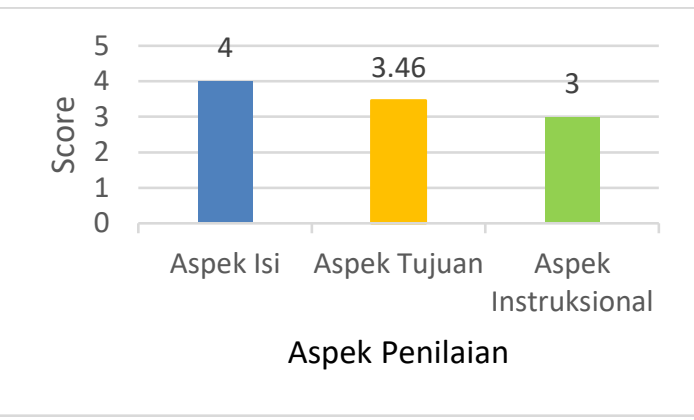

Gambar 26. Grafik Tanggapan Ahli Materi

Hasil validasi oleh ahli materi terhadap uji kelayakan game menunjukan bahwa dari aspek materi, game edukasi digital memperoleh scor rata-rata 3,48 (baik sekali). Adapun rincian yang di peroleh untuk aspek isi memperoleh jumlah rata-rata score 4 (baik sekali), aspek tujuan memperoleh jumlah rata-rata score 3,46 (baik sekali). Sedangkan untuk 
aspek instruksional memperoleh jumlah rata-rata score 3 (baik).

\section{Implementation}

Game edukasi digital "Advanture of Plant" di implementasikan kepada siswa kelas X MIPA 1 dan X MIPA 2 di SMA N 1 Kutasari dengan jumlah total siswa yaitu 60 dan guru biologi. Hasil dari penilaian game dari guru dapat dilihat pada gambar berikut:

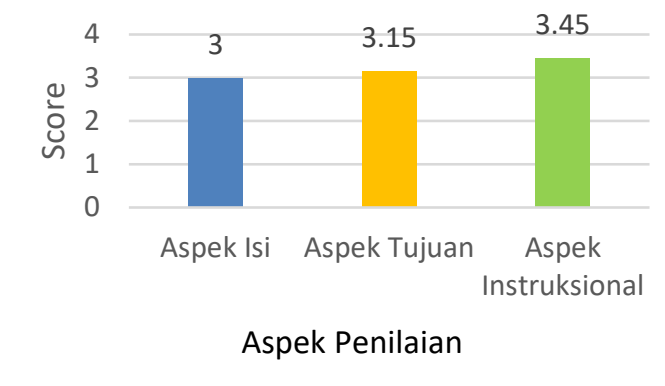

Gambar 27. Grafik Tanggapan Guru

Penilaian guru terhadap game edukasi digital memperoleh score rata-rata 3,23 (baik sekali). Adapun rincian yang di peroleh untuk aspek isi memperoleh ratarata dengan jumlah score 3 (baik), aspek tujuan memperoleh rata-rata dengan jumlah score 3,15 (baik). Sedangkan untuk aspek instruksional memperoleh rata-rata dengan jumlah score 3,45 (baik sekali).

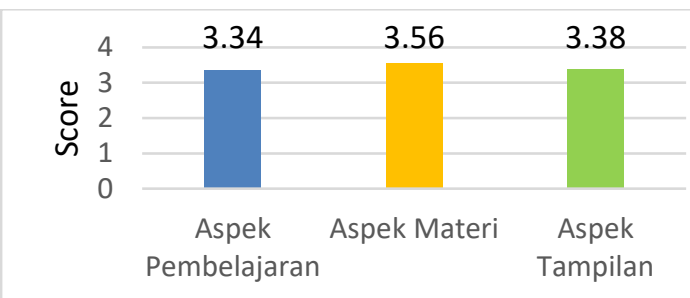

Aspek Penilaian

Gambar 28. Grafik Tanggapan Siswa

Penilaian siswa terhadap game edukasi digital memperoleh score rata-rata 3,38 (baik sekali). Adapun rincian yang di peroleh untuk aspek pembelajaran memperoleh rata-rata dengan jumlah score 3,34 (baik sekali). Untuk aspek materi memperoleh rata-rata dengan jumlah score 3,56 (baik sekali), sedangkan untuk aspek tampilan memperoleh rata-rata dengan jumlah score 3,38 (baik sekali).

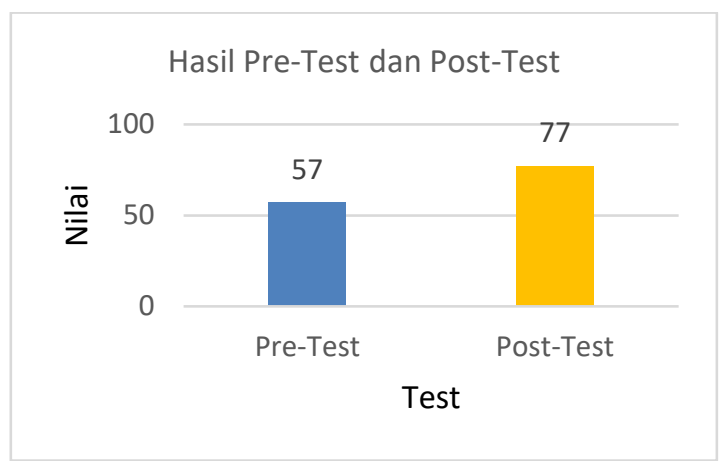

\section{Gambar 29. Grafik Uji N-Gain}

Penilaian secara keseluruhan menggunakan uji $\mathrm{N}$-Gain diperoleh hasil dengan nilai 0,47 dengan kategori sedang (Tabel 2). Implementasi game edukai digital pada pembelajaran materi plantae menunjukan adanya peningkatan hasil belajar berupa post-test. Sebelum menggunakan game edukasi digital siswa memperoleh hasil belajar berupa pre-test dengan rata-rata nilai 57. Siswa mengalami peningkatan pada nilai posttest setelah menggunakan game edukasi sebagai media pembelajaran dengan ratarata nilai 77 .

\section{Evaluation}

Pada tahap evaluasi dilakukan perbaikan game edukasi digital berdasarkan penilaian, komentar dan saran yang didapatkan dari ahli media, ahli materi, guru dan siswa dalam bentuk angket penilaian terhadap game edukasi digital "Advanture of Plant". Sehingga harapanya diperoleh game edukasi digital yang layak untuk digunakan sebagai media pembelajaran Biologi materi Plantae kelas X SMA.

\section{PEMBAHASAN}

Berdasarkan hasil penelitian yang dilakukan dengan menggunakan media pembelajaran yaitu berbasis game edukasi digital "Advanture of Plant". Penggunaan media pembelajaran berbasis game edukasi digital membantu siswa mempermudah memahami konsep dasar Biologi khususnya materi Plantae kelas X. 
Pada analisis hasil kebutuhan siswa menunjukkan siswa lebih lebih tertarik dalam memahami materi pembelajaran dengan menggunakan media yang menghibur, salah satunya yaitu media game edukasi digital. Hal tersebut ditunjukkan dengan pengguanaan smartphone oleh siswa yang hampir setiap harinya menggunakan smartphone. Hal ini diperkuat oleh penelitian yang dilakukan Setyawan (2019) yang menyatakan bahwa cakupan materi yang cukup luas sehingga dibutuhkan media yang sesuai dengan karakter pada materi plantae. Penggunaan media berbasis permainan diperlukan untuk membantu siswa dalam memahami konsep dasar materi dengan hal yang menyenangkan.

Model pengembangan yang digunakan dalam penelitian ini yaitu model pengembangan ADDIE. Model pengembangan yang di aplikasikan terhadap game edukasi digital "Advanture of Plant" disusun berdasarkan data analisis kebutuhan, desain dan flowchart. Penggunaan aplikasi media game dengan Unity 2D version 2019 untuk menyusun game edukasi.

"Advanture of Plant" merupakan game yang sangat menarik selain dari desain, grafik, karakter dan tantangan bagi pengguna dalam game. Pada game "Advanture of Plant" terdapat tiga level, didalam game sudah disesuaikan dengan $\mathrm{KD}$ dan indikator materi plantae. Tiga level tersebut mencangkup materi lumut (Bryophyta), paku (Pterydophyta) dan tumbuhan berbiji (Spermatophyta). Dari setiap level memiliki tantangan dan kesulitan yang berbeda-beda, maka dari itu pemain harus benar-benar dapat menguasai materi plantae yang ada didalamnya agar dapat menyelesikan petualanganya dan membuka soal evaluasi. Dwiyono, (2017), menyatakan bahwa dengan menambahkan animasi pengalaman user akan lebih baik karena penambahan improvisasi yang menyenangkan sehingga outcome pembelajaran lebih tinggi dibandingkan dengan perangkat pedagogik lainya seperti video, audio dan gambar. Tidak hanya tantangan yang menjadi hal menarik lainnya, namun keberlanjutan dengan adanya soal evaluasi. Sehingga siswa akan di uji mengenai pengetahuan tentang materi plantae.

Menurut Susanto (2013), dengan adanya tantangan dan aturan di dalam game siswa dituntut untuk mempelajari cara-cara yang harus dilakukan untuk menaklukan tantangan yang diberikan. Sehingga game dapat digunakan sebagai sebuah sistem instruksional yang terdapat konten pembelajaran didalamnya. Terdapat 20 butir soal dan diberikan batasan waktu untuk menjawab sekitar 40 detik untuk menjawab soal. Setiap soal yang benar akan diberikan point sebanyak 5 dan jika salah akan diberikan nilai 0 . Pengguna akan mengetahui score yang didapatkan berdasarkan jawaban benar yang berhasil di jawab. Dengan jumlah total score jika jawaban semua benar adalah 100. Jumlah score yang didapatkan dapat dibagikan melalui media sosial. Supriyono (2019), menyatakan bahwa selain memiliki peran penting dalam meningkatkan prestasi dan sebagai alat bantu proses belajar. Game edukasi juga dapat dipergunakan untuk merangsang pikiran, perasan, perhatian dan kemampuan kognitif siswa.

Penilaian game oleh ahli media dan ahli materi bertujuan untuk mengetahui validitas terhadap kelayakan game sebelum dilakukan implementasi kepada siswa. Penilaian kelayakan game edukasi digital oleh ahli media memperoleh ratarata score keseluruhan 3,23. Skor tersebut dikatakan baik, karena rata-rata score yang didapatkan berada di rentang score 2,75 < $\mathrm{X} \leq 3,25$ (Tabel 1). Penilaian kelayakan game edukasi digital meliputi indikator media pembelajaran yang harus ada di dalam game. Berdasarkan indikator, game layak digunakan sebagai media pembelajaran dengan perbaikan pada pada button dan sound effect. 
Arif (2016), menyatakan bahwa game edukasi selain berisi materi pendidikan yang dirancang sebagai permainan interaktif dengan unsur kreativitas, petualangan, motivasi, bermain, ketrampilan, bebas, mendidik, logika, kegemaran, mandiri dan mengambil keputusan. Game edukasi dapat mendorong siswa untuk belajar aktif dan kreatif melalui beberapa tantangan yang diberikan. Dwiyono (2017), menerangkan bahwa penggunaan game dalam pembelajaran dapat menjadikan pembelajaran menjadi lebih santai dan dapat merangsang siswa untuk belajar lebih aktif dalam memecahkan masalah. Pembelajaran melalui game edukasi pula suasana pembelajaran menjadi lebih menarik, mengingat sebagian besar siswa saat ini sering meluangkan waktunya untuk bermain game di computer/android. Dengan demikian pengembangan game edukasi sebagai media pembelajaran diharapkan dapat memberikan suasana menyenangkan pada proses pembelajaran.

Penilaian oleh ahli materi terkait game edukasi digital "Advanture of Plant" memperoleh rata-rata score 3,48 dengan kategori baik. Berdasrkan penilaian oleh ahli materi bahwa game layak di gunakan sebagai media pembelajaran. Pengembangan game edukasi digital dikatakan layak karena sudah sesuai dengan KD dan indicator yang harus di capai dalam materi plantae. Sehingga diharapkan dapat membantu siswa dalam memahami konsep dasar pada materi plantae. Ahli materi juga memberikan komentar dan saran terkait dengan tatacara penulisan nama ilmiah tumbuhan, gambar didalam game ada yang tertukar dan kejelasan tentang tingkatan takson dalam klasifikasi. Komentar dan saran yang diberikan oleh ahli materi selanjutnya digunakan sebagai acuan untuk memperbaiki game edukasi digital "Advanture of Plant". Hal tersebut bertujuan agar game edukasi digital "Advanture of Plant" sesuai dengan kompeteni dasar yang terdapat pada materi plantae kelas X. Hikam (2012), menyatakan bahwa penggunan multimedia yang baik mampu meningkatkan kemampuan komunikasi, motivasi dan kemampuan belajar mandiri. Sriwahyuni (2016), juga menyatakan bahwa media pembelajaran yang baik mampu menyampaikan materi pembelajaran sesuai dengan tujuan pembelajaran yang telah dirumuskan pada proses perancangan pembelajaran.

Tahap selanjutnya setelah dilakukan validasi game oleh ahli media dan ahli materi game, game akan di implementasikan didalam kegiatan pembelajaran. Tahap implementasi game edukasi digital yang telah dibuat akan diberikan kepada guru dan siswa SMA N 1 Kutasari sebagai media pembelajaran biologi materi Plantae kelas X MIPA. Selanjutnya akan dilakukan penilaian game oleh guru dan siswa meggunkan angket. Didapatkan hasil penilaian game oleh guru terhadap kelayakan game edukasi digital "Advantur of Plant" untuk aspek isi dan tujuan memperoleh rata-rata dengan jumlah score 3,11 (baik), sedangkan untuk aspek instruksional memperoleh rata-rata dengan jumlah score 3,45 (baik sekali). Sehingga diproleh hasil perhitungan jumlah rata-rata total keseluruhan aspek dengan score 3,23 (baik). Berdasarkan hasil penilaian tersebut, maka game masuk kedalam kategori 'baik' berdasarkan nilai rata-rata total dengan score 3,23 berada di rentang score $2,75<\mathrm{X} \leq 3,25$. (Tabel 1 )

Selain memberikan penilaian, guru juga memberikan komentar yang berkaitan dengan kelayakan game edukasi digital. Berdasarkan penilaian oleh guru maka game edukasi digital layak di gunakan sebagai media pembelajaran karena sangat membantu guru dalam menyampaikan pembelajaran Biologi materi Plantae yang dapat diakses setiap saat. Lufri (2017), menyatakan bahwa penggunaan game edukasi digital tidak terbatas pada saat waktu pembelajaran saja namun juga dapat digunakan di luar jam pembelajaran. 
Selain menarik media juga harus mampu mengatasi keterbatasan waktu pembelajaran, sehingga dapat digunakan didalam dan diluar jam pembelajaran.

Berdasarkan hasil implementasi game edukasi digital dengan judul "Advanture of Plant" memberikan pengaruh dalam proses pembelajaran maupun hasil kegiatan pembelajaran. Dapat dilihat dari penilaian yang di berikan oleh siswa dengan kategori baik, yang menunjukan bahwa game edukasi digital juga berpengaruh terhadap kegiatan pembelajaran. Hasil belajar siswa juga dapat dilihat berdasarkan perhitungan $\mathrm{N}$ Gain dari score Pre-Teset dan Post-Test dengan hasil ahir nilai postest lebih baik dibandingan dengan nilai pretest. Berdasarkan hasil perhitungan N-gain total juga didapatkan hasil score dengan jumlah 0,47 dengan kategori sedang. Hai ini menunjukan bahwa game edukasi digital memberikan pengaruh untuk membantu siswa dalam memahami konsep pada Biologi materi Plantae. Lufri (2017), juga menyatakan bahwa penggunaan media akan berpengaruh terhadap daya ingat peserta didik sehingga kualitas pembelajaran memiliki nilai yang tinggi.

Penggunaan game edukasi digital dalam upaya meningkatkan pemahaman konsep dipengaruhi oleh beberapa faktor. (Dewi dkk., 2017), menyatakan bahwa faktor yang mempengaruhi antara lain yaitu pengalaman terhadap penggunaan game sebagai media pembelajaran yang masih minim. Penggunaan game selama ini hanya game non-edukasi sehingga tidak berkaitan dengan kegiatan pembelajaran. Penggunan dan keterbatasan teknologi pada setiap indifidu. Lingkungan sebagai factor yang berkaitan dengan pemanfaatan teknologi yang ada. Supriyono (2019), menyatakan bahwa media pembelajaran merupakan bagian intergral dari keseluruhan proses pembelajaran. Artinya bahwa media pembelajaran merupakan komponen yang tidak dapat berdiri sendiri melaiknkan saling berhubungan dengan komponen lain dalam rangka menciptakan situasi belajar yang di harapkan.

\section{KESIMPULAN}

Berdasarkan hasil penelitian yang diperoleh dari ahli media, ahli materi, guru dan siswa game edukasi digital "Advanture of Plant" menunjukan hasil rata-rata penilaian baik sampai dengan baik sekali. Sehingga game edukasi digital yang di kembangkan layak digunakan sebagai media pembelajaran. Berdasarkan hasil implementasi menunjukan game edukasi digital "Advanture of Plant" berpengaruh (sedang) terhadap peningkatan pemahaman konsep yang dapat di lihat dari hasil belajar siswa pada materi plantae.

\section{SARAN}

Berdasarkan hasil penelitian tersebut, maka peneliti memberikan saran : 1) Perlunya pengembangan lebih lanjut terhadap game edukasi digital untuk meningkatkan pemahaman konsep pada materi Plantae. 2) Perlunya pemanfaatan teknologi lebih lanjut dalam pembelajaran biologi materi plantae. 3) Perlunya uji coba lebih lanjut untuk mengetahui kelayakan game edukasi digital sebagai media pembelajaran.

\section{DAFTAR RUJUKAN}

Anbia, W. 2013. Survey Penggunaan Media Pembelajaran pada Mata Pelajaran Ekonomi Materi Akuntansi Kelas XI IPS SMA Negeri 1 Driyorejo Gresik. Jurnal Pendidikan Akuntansi (JPAK), 1(3).

Arif, M.N. 2016. Pengembangan game edukasi interaktif pada mata pelajaran komposisi foto digital kelas XI di SMK negeri 1 Surabaya. IT-Edu: Jurnal Information Technology and Education, 1(02).

Budiana, H., Sjafirah, N., \& Bakti, I. 2015. Pemanfaatan teknologi informasi dan komunikasi dalam 
pembelajaran bagi para guru SMPN 2 Kawali desa Citeureup kabupaten Ciamis. Dharmakarya, 4(1).

Dewi, E.P., Suyatna, A., Abdurrahman, A., \& Ertikanto, C. 2017. Efektivitas Modul dengan Model Inkuiri untuk Menumbuhkan Keterampilan Proses Sains Siswa pada Materi Kalor. Tadris: Jurnal Keguruan dan Ilmu Tarbiyah, 2(2), 105-110.

Dopo, F.B., \& Ismaniati, C. 2016. Persepsi guru tentang digital natives, sumber belajar digital dan motivasi memanfaatkan sumber belajar digital. Jurnal Inovasi Teknologi Pendidikan, 3(1), 13-24.

Dwiyono. 2017. Pengembangan Game Edukasi Sebagai Media Pembelajaran Interaktif Pada Kompetensi Dasar Mendeskripsikan Penggunaan Peralatan Tangan (Hand Tools) dan Peralatan Bertenaga (Power Tools). Program Studi Pendidikan Teknik Mekatronika Vol. 7, No. 4, Juli 2017, 343-351.

Dwiyono, D. 2017. Pengembangan Game Edukasi Sebagai Media Pembelajaran Interaktif Pada Kompetensi Dasar Mendeskripsikan Penggunaan Peralatan Tangan (Hand Tools) Dan Peralatan Bertenaga (Power Tools). Jurnal Pendidikan Teknik Mekatronika, 7(4).

Falahudin, I. 2014. Pemanfaatan media dalam pembelajaran. Jurnal Lingkar Widyaiswara, 1(4), 104117.

Firdos, N.A.Y. 2012. Pengaruh model pembelajaran Predict, Observe, Explain dengan bantuan media foto pada materi struktur dan fungsi jaringan tumbuhan. Universitas Negeri Semarang.

Herniati, R., Sulistri, E., \& Rosdianto, H. 2017. Penerapan Model Predict Observe Explain Dengan Pendekatan Learning by Doing
Untuk Meningkatkan Hasil Belajar Siswa. Jurnal Fisika Flux: Jurnal Ilmiah Fisika FMIPA Universitas Lambung Mangkurat, 14(2), 120124.

Hikam, A.R. 2012. Pengembangan Game Edukasi Visual Novel Berbasis Pembangunan Karakter Pada Materi Pelestarian Lingkungan. Universitas Negeri Semarang.

Kemendikbud. (2016, Desember 2020 Kamis). Kemendikbud.go.id. Retrieved from http://vervalsp.data.kemdikbud.go.i $\mathrm{d} /$ prosespembelajaran/file/Permend ikbud_Tahun2016_Nomor022_La mpiran.pdf, Jam 23:06

Lufri, D. O. 2017. Pengembangan Media Pembelajaran Berbentuk Permainan Monopoli Tumbuhan (MONTUM) Tentang Struktur Dan Fungsi Tumbuhan Untuk Peserta Didik Kelas VIII SMP. Journal Biosains Volume 1 Nomor 22017 ISSN : 2354-8371, 174-182.

Muhson, A. 2010. Pengembangan media pembelajaran berbasis teknologi informasi. Jurnal Pendidikan Akuntansi Indonesia, 8(2).

Munir, M. 2014. Pengembangan media pembelajaran interaktif kompetensi dasar register berbasis inkuiri terbimbing. Jurnal pendidikan teknologi dan kejuruan, 22(2), 184190.

Nining, D., Lestari, N., \& Japa, L. 2019. Analisis Miskonsepsi Menggunakan Teknik Modifikasi Certainty of Response Index dalam Pembelajaran Tentang Kingdom Plantae dan Animalia Pada Siswa Di Kelas $X$ IPA SMAN 1 Pringgabaya Lombok Timur Tahun 2016. Jurnal Ilmiah Pendidikan Indonesia, 1(1), 49-56.

Novaliendry, D. 2013. Aplikasi game geografi berbasis multimedia interaktif (studi kasus siswa kelas IX SMPN 1 RAO). Jurnal 
Teknologi Informasi \& Pendidikan, 6(2), 106-118.

Noviyanti, A. d. 2014. Pemahaman Konsep Siswa pada Materi Plantae Di Kelas X SMAN Aceh Besar. Serambi Akademica, Vol. II, No. 1, Mei 2014 ISSN : 2337 - 8085, 2329.

Panjaitan, R.G.P., Titin, T., \& Putri, N.N. 2020. Multimedia Interaktif Berbasis Game Edukasi sebagai Media Pembelajaran Materi Sistem Pernapasan di Kelas XI SMA. Jurnal Pendidikan Sains Indonesia (Indonesian Journal of Science Education), 8(1), 141-151.

Pramita, A. 2016. Pengembangan Media Permainan Ular Tangga pada Materi Senyawa Hidrokarbon Kelas XI SMA untuk Meningkatkan Pemahaman Konsep Siswa (Development Of Media Snakes and Ladders Game On Hydrocarbon Compound XI Grade Senior High School To Improve Understanding The Concept of Students). Unesa Journal of Chemical Education, 5(2).

Priandana, V.F.D. 2015. pengembangan media pembelajaran multimedia interaktif berbantuan software macromedia flash pada kompetensi dasar menerapkan macam-macam gerbang dasar rangkaian logika di SMK Negeri 2 Bojonegoro. Jurnal Pendidikan Teknik Elektro, 4(1).

Rahma, Y.A. 2014. Pengembangan Permainan Gomoku sebagai Permainan Edukatif untuk Sumber Belajar pada Materi Dunia Tumbuhan. BioEdu, 3(3).

Rahman, R.A., \& Tresnawati, D. 2016. Pengembangan game edukasi pengenalan nama hewan dan habitatnya dalam 3 bahasa sebagai media pembelajaran berbasis multimedia. Jurnal Algoritma, 13(1), 184-190.

Ramansyah, W. 2015. Pengembangan education game (EDUGAME) berbasis android pada mata pelajaran bahasa inggris untuk peserta didik sekolah dasar. Jurnal Ilmiah Edutic, 2(1), 1-9.

Risnani, L.Y., \& Adita, A. 2019. Game Edukasi Digital untuk Meningkatkan Minat Belajar Peserta Didik pada Mata Pelajaran IPA. Proceeding of The URECOL, 376-384.

Rohwati, M. 2012. Penggunaan education game untuk meningkatkan hasil belajar IPA biologi konsep klasifikasi makhluk hidup. Jurnal Pendidikan IPA Indonesia, 1(1).

Rusdi, J.F., Salam, S., Abu, N.A., Baktina, T.G., Hadiningrat, R.G., Sunaryo, B., . . . Laurenty, F. 2019. ICT research in Indonesia. SciTech Framework, 1(1), 1-23.

Saputra, I.K.R., Pudjawan, K., \& Tastra, I.D.K. 2017. Pengembangan Multimedia Interatif Berbasis Game Berorientasi Pendidikan Karakter Pada Mata Pelajaran Bahasa Inggris Kelas IV DI SD Mutiara Singaraja Tahun Pelajaran 2017/2018. Jurnal Edutech Undiksha, 5(2), 160-167.

Sari, K.W., Saputro, S., \& Hastuti, B. 2014. Pengembangan game edukasi kimia berbasis role playing game (RPG) pada materi struktur atom sebagai media pembelajaran mandiri untuk siswa kelas X SMA di kabupaten Purworejo. Jurnal Pendidikan Kimia, 3(2), 96-104.

Setyawan, P., \& Ibrahim, M. 2019. Pengembangan Media Flashcard Berbasis Pictorial Riddle Pada Materi Plantae untuk Meningkatkan Motivasi dan Pemahaman Konsep Siswa SMA/MA Kelas X. Berkala Ilmiah Pendidikan Biologi (BioEdu), 8(2). Setyawan, W.C., Sulthoni, S., \& Ulfa, S. 2019. Pengembangan Multimedia Game Edukasi Ipa Lapisan Bumi Untuk MTS. Jurnal Kajian Teknologi Pendidikan, 2(1), 30-36. 
Sriwahyuni, N.A. 2016. Pengembangan Media Pembelajaran Game Edukasi Pada Mata Pelajaran Ekonomi Kelas X IIS SMA Laboratorium Universitas Negeri Malang. Jurnal Pendidikan Ekonomi (Economic Education Journal), 9(2).

Supriyono, S. 2019. Pentingnya Media Pembelajaran Untuk Meningkatkan Minat Belajar Siswa Sd. Edustream: Jurnal Pendidikan Dasar, 2(1), 43-48.

Susanto, S., Dewi, N.R., \& Irsadi, A. 2013. Pengembangan multimedia interaktif dengan education game pada pembelajaran IPA terpadu tema cahaya untuk siswa SMP/MTs. Unnes Science Education Journal, 2(1).

Wulandari, R., Susilo, H., \& Kuswandi, D. 2017. Penggunaan Multimedia Interaktif Bermuatan Game Edukasi untuk Meningkatkan Aktivitas dan Hasil Belajar Siswa Sekolah Dasar. Jurnal Pendidikan: Teori, Penelitian, dan Pengembangan, 2(8), 1024-1029.

Yudasmara, G.A., \& Purnami, D. 2015. Pengembangan Media Pembelajaran Interakif Biologi Untuk Meningkatkan Hasil Belajar Siswa SMP. Jurnal Pendidikan dan Pengajaran, 